\title{
UMA IMPRENSA PARA O TEATRO
}

Luciana Penna-Franca*

RESUMO: A compreensão da história do teatro amador carioca no final do século XIX e início do XX é possível, em grande medida, pelos periódicos dedicados aos "assuntos teatrais". Essa produção periodista é significativa tanto em número quanto na sua diversidade, revelando não apenas o lugar que o teatro ocupava na capital, como o reconhecimento da imprensa como espaço de divulgação de peças, formação de públicos e opinião, projeção de artistas, etc., como também de relações pessoais e pedidos e trocas de favores entre empresários e jornalistas. Mais ainda, a produção de jornais pelos clubes dramáticos amadores demonstra a sua compreensão do papel que a imprensa ocupava na divulgação de formas de agir e pensar além dos palcos, mas no próprio cotidiano.

PALAVRAS-CHAVE: Imprensa; Rio de Janeiro; Teatro amador; Associativismo.

\section{A press for the theater}

RESUME: Understanding the history of the amateur theater at the end of the XIXth century and the beginning of the XXth is possible, largely, because of the newspapers dedicated to the "theatrical affairs". Such publications are important for the quantity and the diversity, revealing not only the place occupied by the theater in the capital, but also for the recognition of the press as a means of disclosure of plays, public education and opinion, artist projection, etc, not to mention personal affairs and requests, and the exchange of favors among managers and journalists. Even more, the press production of the dramatic amateurs clubs demonstrate the understanding of its role in the dissemination of ways to act and think beyond the stage and in the everyday life.

KEYWORDS: Press; Rio de Janeiro; Amateur theater; Associativism.

\section{Una prensa para el teatro}

RESUMEN: Comprender la historia del teatro amateur carioca a finales del siglo XIX y principios del XX es posible, en gran medida, por las publicaciones periódicas dedicadas a los "asuntos teatrales". Esta producción periódica es significativa tanto por su cantidad como por su diversidad, y revela no sólo el lugar que el teatro ocupaba en la capital, sino el reconocimiento de la prensa como espacio de divulgación de piezas, formación de públicos y opiniones, proyección de artistas, etc., así como también de relaciones personales y peticiones e intercambios de favores entre empresarios y periodistas. Además, la producción de periódicos por los clubes dramáticos amateurs demuestra su comprensión del papel que la prensa desempeñaba en la divulgación de las formas de actuar y pensar fuera de los escenarios, es decir, en la propia vida cotidiana.

PALABRAS CLAVE: Prensa; Río de Janeiro; Teatro amateur; Asociativismo.

* Doutora em História pela Universidade Federal Fluminense, onde cursou também duas pós-graduações latosensu: História Contemporânea e Brasil Pós-30. Atualmente trabalha para a Prefeitura de Teresópolis, Rio de Janeiro. Contato: Estrada Clube do Lago 130, Teresópolis - RJ, Brasil. Email: lucianagremlim@ gmail.com. 


\section{Uma imprensa para o teatro}

Entre as décadas de 1871 e 1920, o Rio de Janeiro era palco de apresentações teatrais de companhias profissionais, estrangeiras e, em especial, de sociedades dramáticas amadoras, objeto principal deste artigo. O grande número de sociedades particulares existentes na cidade é uma evidência dessa relevância e a distribuição dos grupos amadores por todos os bairros, inclusive, a região central, indica que o fazer teatral era uma prática social disseminada por toda urbe carioca. A existência de uma seção fixa na quase totalidade dos periódicos, seja nos grandes diários ou nos jornais e revistas de menor circulação, dedicada à crítica de espetáculos, propaganda ou informação sobre peças, saraus dramáticos e bailes realizados pelas associações dramáticas constitui outra evidência do apelo do teatro para a sociedade carioca

Os jornais analisados nesta investigação elegeram o teatro como assunto importante para uma coluna ou mesmo para todo o espaço do periódico, produzidos por pessoas interessadas ou ligadas ao teatro profissional ou amador, ou contando com a colaboração destas para falar sobre os assuntos teatrais. Os proprietários ou editores eram escritores, artistas, grupos operários, imigrantes ou mesmo os associados dos grêmios dramáticos amadores. Essa produção periodista é significativa tanto em número quanto na sua diversidade, revelando não apenas o lugar que o teatro ocupava na capital, como o reconhecimento da imprensa como espaço de divulgação de peças, formação de públicos e opinião, projeção de artistas, etc., como também de relações pessoais e pedidos e trocas de favores entre empresários e jornalistas. Mais ainda, a produção de jornais pelos clubes dramáticos amadores demonstra a sua compreensão do papel que a imprensa ocupava na divulgação de formas de agir e pensar além dos palcos, mas no próprio cotidiano.

Nas colunas desses periódicos e da crítica teatral, os jornalistas recomendavam peças e companhias de atores, debatiam necessidades do meio, como a criação de uma escola dramática ou um número maior de textos de autores brasileiros, comentavam sobre as salas nos teatros, a tradução de textos estrangeiros e a atuação dos artistas. Além das críticas e divulgação da programação em cartaz, havia as histórias peculiares que aconteciam nos teatros da cidade, convocação de artistas para ensaios e convites aos leitores para participarem dos eventos promovidos por este ou aquele clube ou grêmio dramático. Em alguns desses periódicos encontramos biografias de atores e atrizes, informações sobre companhias dramáticas e, também, discussões que, muitas vezes, deixavam claras as ideias daquele articulista ou crítico. Por meio da imprensa "teatral" muitos grupos se dedicaram ativamente à 
constituição de públicos, autores e companhias teatrais na cidade além de atuarem como formadores de opinião sobre teatro. Nas suas páginas pude identificar como alguns jornalistas, atores, diretores e sócios de sociedades amadoras, compreendiam o fazer teatral dos amadores.

Para além do espaço aberto às notícias relativas ao teatro, atores e espetáculos nas páginas da imprensa empresarial, de bairro ou operária, merece destaque a existência de um número significativo de periódicos dedicados exclusivamente aos "interesses teatrais", alguns deles produzidos pelos próprios sócios de clubes de amadores. Os jornais e revistas "teatrais" localizados durante a pesquisa variam em propostas, objetivos e grupos editores. A maioria teve curta duração ou não foi preservada, enquanto alguns poucos tiveram vida mais longa e permitem entrever os bastidores de espetáculos, conhecer a trajetória de atores e companhias teatrais, inclusive das sociedades amadoras, além de identificar ideias, propostas e alternativas para o teatro que mobilizaram diferentes grupos ao longo do tempo. Pouco explorados pelos pesquisadores, esses periódicos constituem registros fundamentais para a história da imprensa e do teatro, porque trazem as opiniões e comentários de sujeitos históricos diversos envolvidos com experiências teatrais, tanto os que estavam nas manchetes quanto os que as escreviam. Os títulos mais antigos localizados nas coleções de periódicos classificados como "teatrais" existentes nas instituições de guarda documental do Rio de Janeiro datam de 1839 ${ }^{1}$, mas em função da maior concentração dos clubes dramáticos entre as décadas de 1870 e 1920, este foi o período privilegiado na seleção dos periódicos. Grande parte dos exemplares encontrados são apenas os primeiros números do primeiro ano de sua edição, o que impediu acompanhar suas propostas e interesses ao longo do tempo. Alguns possuem diversos exemplares que continuam ao longo dos anos, mas estes são em menor número.

Os títulos dos jornais dedicados ao teatro são bastante reveladores de suas propostas e objetivos. No centro da cidade, estava a redação da revista $O$ Theatro, dirigido por Nazareth Menezes, e, já pelo título é possível perceber que era inteiramente dedicada aos assuntos teatrais, reservando a coluna Amadores, para tratar, exclusivamente, dos palcos particulares. ${ }^{2}$ Não obstante, comentava sobre o teatro estrangeiro e priorizava o teatro comercial carioca. $\mathrm{O}$ periódico A Imprensa publicou a história da revista e sua reprodução foi feita na segunda edição do próprio $O$ Theatro: a revista teria sido fundada há cinco anos por Adhemar Barboza Romeu e reaparecido em 1911, sob a direção de Nazareth Menezes e secretariada por Januario Osorio. No entanto, o redator de A Imprensa comenta que essa ligação não foi explicada no artigo de apresentação da revista. O jornalista comenta ainda que o primeiro número 
tem abundante matéria e os retratos do malogrado escritor teatral Arthur Azevedo (na capa), Adolpho de Faria, Esther Bergerat, Guilhermina Rocha, França Junior, Marzullo, João de Deus e Benjamin de Oliveira. ${ }^{3}$

O diretor Nazareth Menezes era um "colega de imprensa" e ao observar os artistas prestigiados com retratos no primeiro número, percebe-se que a intenção dos editores da revista era valorizar o teatro profissional, seus empresários e escritores, demonstrando clara aliança entre os mesmos e a revista. O próprio colaborador efetivo João Claudio, era, na verdade, um disfarce por ser um "conhecido e apreciado escritor teatral", conforme revelou o comentário de $O$ Rio $N u ́$ na própria revista ${ }^{4}$.

Nesse sentido, no artigo $O$ cartel dos tablados no Rio de Janeiro do século XIX: a empresa teatral internacional, Fernando Antonio Mencarelli demonstra as alianças entre imprensa e empresários teatrais, assim como a força desses grupos no próprio negócio do teatro. $\mathrm{O}$ historiador analisa um imbróglio entre três empresários importantes que administravam dois teatros: Jacinto Heller, do teatro Santana e Braga Junior e Sousa Bastos, do teatro Príncipe Real. Heller e Bastos portugueses e Braga Junior, brasileiro que optou pela nacionalidade portuguesa. $\mathrm{Na}$ intenção de não concorrer entre si, os empresários produziram um documento firmado em cartório em 1884, determinando a não contratação de empregados que deixassem a companhia dos outros membros do cartel, e para estipular preços de textos originais, pressão sobre os preços de anúncios em jornais, teto salarial para os atores. No entanto, a tentativa de cartelizar empresas teatrais não deu certo. Envolvendo a disputa por três atrizes importantes das duas empresas, a questão possibilita conhecer as relações de trabalho e produção dessas empresas, os conflitos entre as categorias profissionais de atores e empresários, como enfrentavam a concorrência e estabeleciam "controle sobre todas as dimensões do setor de negócios em torno do teatro alegre e, de forma evidente, a internacionalização do setor". 5

Procurando regularizar a concorrência na escolha das peças a serem montadas e impedindo a concorrência nas excursões pelas províncias, aqueles empresários definiam salários e preços de ingressos, além de multas para o descumprimento do contrato. Os artigos do acordo eram bastante específicos na definição das publicações jornalísticas nas quais anunciariam seus espetáculos, o tamanho de seus anúncios arranjados de comum acordo e a pressão sobre os jornais para a manutenção dos preços pelo espaço publicitário. Demonstrando claramente a defesa dos interesses dos próprios empresários, o contrato revela 
importante atuação dos mesmos em relação a imprensa, desde a imposição de preços e tamanhos de anúncios à divulgação de peças e formas de controle da concorrência.

Os dois últimos exemplos se referem ao teatro profissional e as tentativas de controle por parte dos empresários, inclusive, através de alianças com a grande imprensa. No entanto, a pequena imprensa teatral, que tratava tanto do teatro comercial como o amador, também se constituia como força ativa na divulgação de ideias, peças, formação de público e de opinião. Voltemos à esses periódicos.

O Espectador: órgão consagrado à arte dramática, publicado com alguma regularidade entre 1881 e 1885 , também como proposto no título e subtítulo, tratava somente dos "interesses teatrais" - como enfatiza a mudança no subtítulo em 1882. Apesar deste periódico servir aos interesses do teatro comercial e incorporar o discurso de um grupo de intelectuais que valorizavam o "teatro de qualidade" e o "teatro nacional", os amadores estavam presentes em todas as edições encontradas sem, no entanto, uma seção especial para os mesmos. Encontrei mais 2 periódicos com o mesmo título, um de 1876 e outro de 1904, mas não parecem ser continuação ou ter nenhuma ligação entre eles. Mesmo defendendo os interesses do teatro comercial, os amadores estavam presentes em muitos desses periódicos. Dois periódicos intitulados A Platea, o primeiro de 1883, tinha o subtítulo: revista theatral e humoristica, e o segundo, de 1914: semanario theatral, literario e humoristico. Este dedicava-se exclusivamente ao teatro profissional. O mais antigo, apesar de se anunciar "pertencente a uma sociedade", sem especificar qual, também priorizava as notícias dos teatros comerciais, mas reservava um espaço para comentar sobre as festas e récitas promovidas pelos amadores. O suplemento da Revista Lettras e Artes intitulado A Epoca Theatral, reservou uma coluna na página 2 para o teatro nos subúrbios. Mais um jornal que privilegiava o teatro comercial, porém defendia nessa coluna que o público dos subúrbios estimulasse "material e moralmente" os amadores, lembrando que "vultos queridíssimos" do "grande teatro" foram revelados nos palcos dos "teatrinhos"

Para demonstrar essa diversidade de periódicos dedicados aos "interesses teatrais" elaborei um quadro com alguns títulos significativos, que publicavam, pelo menos, uma coluna sobre os amadores. 
Quadro 1: Periódicos dedicados aos assuntos teatrais.

\begin{tabular}{|c|c|c|c|c|}
\hline TÍTULO & SUBTÍTULO & $\begin{array}{l}\text { FUNDAÇ̃̃OO } \\
\text { Período de } \\
\text { circulação }\end{array}$ & $\begin{array}{c}\text { PROPRIETÁRIOS, } \\
\text { REDATORES E } \\
\text { DIRETORES }\end{array}$ & PREÇO \\
\hline $\begin{array}{l}\text { A Epoca } \\
\text { Theatral }\end{array}$ & & 1917 & $\begin{array}{l}\text { Suplemento da Revista Lettras } \\
\text { e Arte }\end{array}$ & \\
\hline A Lyra & $\begin{array}{l}\text { Orgão da Arcadia } \\
\text { Dramatica Esther de } \\
\text { Carvalho }\end{array}$ & $1888-1890$ & $\begin{array}{l}\text { Arcadia Dramatica Esther de } \\
\text { Carvalho }\end{array}$ & Gratuito \\
\hline A Madrugada & $\begin{array}{l}\text { Periodico litterario e } \\
\text { recreativo dedicado ao } \\
\text { Euterpe Club }\end{array}$ & 1902 & $\begin{array}{l}\text { Redator chefe: Gaudencio } \\
\text { Cardoso; redator secretário: } \\
\text { Manoel Ferraz; redator gerente: } \\
\text { A. Nepomuceno de Araújo }\end{array}$ & $\begin{array}{l}\text { Assinatura } \\
\text { trimestral } 1 \$ 000\end{array}$ \\
\hline A Platea & $\begin{array}{l}\text { Revista teatral e } \\
\text { humorística }\end{array}$ & 1883 & & $\begin{array}{l}\text { Assinatura } \\
\text { números } \\
5 \$ 000 / 48- \\
9 \$ 000\end{array}$ \\
\hline $\begin{array}{l}\text { Almanach } \\
\text { Teatral }\end{array}$ & & 1898 & $\begin{array}{l}\text { Organizado por } \\
\text { Calainho }\end{array}$ Alfredo & \\
\hline $\begin{array}{l}\text { Almanack dos } \\
\text { Theatros }\end{array}$ & & 1896-1909-1910 & $\begin{array}{l}\text { Organizado por Alvarenga } \\
\text { Fonseca e Alfredo Calainho. }\end{array}$ & \\
\hline $\begin{array}{l}\text { Almanaque d'O } \\
\text { Theatro }\end{array}$ & & 1906 & $\begin{array}{l}\text { Organizado por Adhemar } \\
\text { Barbosa Sobrinho. }\end{array}$ & $2 \$ 000$ \\
\hline Amador & $\begin{array}{l}\text { Orgão do } \quad \text { Club } \\
\text { Terpsychore }\end{array}$ & 1886 & $\begin{array}{l}\text { Propriedade do Club } \\
\text { Terpsychore. } \\
\text { Flaviano Gil, Serra e Floridor. }\end{array}$ & Gratuito \\
\hline Binoculo & & $1881-1882$ & & $\begin{array}{l}200 \quad \text { réis/ } \\
\text { Assinatura } \\
\text { anual } 12 \$ 000 / \\
\text { semestral } 7 \$ 000\end{array}$ \\
\hline Chrysalida & $\begin{array}{l}\text { Folha litteraria, critica } \\
\text { e theatral }\end{array}$ & 1873 & & \\
\hline Comedia & & 1920 & & \\
\hline $\begin{array}{l}\text { Comedia } \\
\text { popular }\end{array}$ & $\begin{array}{l}\text { Hebdomanario } \\
\text { illustrado e satyrico }\end{array}$ & 1877 & & $\begin{array}{l}300 \quad \text { réis/ } \\
\text { Assinatura } \\
\text { trimestral } 3 \$ 000\end{array}$ \\
\hline $\begin{array}{ll}\text { Farpas } & e \\
\text { Ribaltas } & \end{array}$ & $\begin{array}{l}\text { Semanario illustrado } \\
\text { de } \\
\text { atualidades e sport }\end{array}$ & 1916 & Redator: Alfredo Ford (Thebas) & 100 réis \\
\hline O Amador & $\begin{array}{l}\text { Periodico litterario do } \\
\text { Club Dramatico } \\
\text { Gonçalves Leite }\end{array}$ & 1888 & Redator: A. Rosario & Gratuito \\
\hline O Artista & 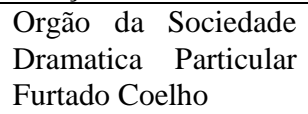 & 1903 & $\begin{array}{l}\text { Sociedade Dramatica Particular } \\
\text { Furtado Coelho }\end{array}$ & \\
\hline O Badalo & $\begin{array}{l}\text { Periodico satyrico, } \\
\text { humoristico, } \\
\text { epigrammatico } \\
\text { debochatico }\end{array}$ & 1893 & $\begin{array}{l}\text { "Propriedade e redação de } \\
\text { vários anônimos de muita } \\
\text { força" }\end{array}$ & \\
\hline O Binoculo & $\begin{array}{l}\text { Semanario theatral, } \\
\text { sportivo e humoristico }\end{array}$ & 1918 & $\begin{array}{l}\text { Diretor: Dr. Santos Figueiro; } \\
\text { secretário: Celestino Silveira; } \\
\text { gerente: Annibal Pacheco }\end{array}$ & 100 réis \\
\hline O Delormista & $\begin{array}{l}\text { Orgão consgrado ao } \\
\text { theatro fluminense e } \\
\text { ao Grupo Delormista }\end{array}$ & 1889 & $\begin{array}{l}\text { Propriedade de Guilherme } \\
\text { Junior }\end{array}$ & 40 réis \\
\hline O Empata & $\begin{array}{l}\text { Semanario illustrado, } \\
\text { pilherico, } \\
\text { epigrammatico } \\
\text { humoristico }\end{array}$ & 1906 & $\begin{array}{l}\text { Diretor artístico: J. Arthur; } \\
\text { redator: A. Barboza }\end{array}$ & 200 réis \\
\hline
\end{tabular}




\begin{tabular}{|c|c|c|c|c|}
\hline O Escandalo & $\begin{array}{l}\text { Orgão do mundo } \\
\text { alegre }\end{array}$ & 1895 & & \\
\hline O Espectador & $\begin{array}{l}\text { Orgão consagrado a } \\
\text { arte dramatica }\end{array}$ & $1881-1885$ & $\begin{array}{l}\text { "Propriedade de uma } \\
\text { associação anônima" }\end{array}$ & 100 réis $^{7}$ \\
\hline O Espectador & & 1876 & Propriedade de José de Azurara & \\
\hline O Espectador & $\begin{array}{l}\text { Periodico theatral } \\
\text { litterario e recreativo }\end{array}$ & 1904 & & \\
\hline O Jasmim & $\begin{array}{l}\text { Orgão do Atheneu } \\
\text { Dramatico Esther de } \\
\text { Carvalho }\end{array}$ & 1888 & $\begin{array}{l}\text { Atheneu Dramatico Esther de } \\
\text { Carvalho }\end{array}$ & Gratuito \\
\hline O Paladino & $\begin{array}{l}\text { Orgão do Club D. } \\
\text { Alumnos de Minerva - } \\
\text { Folha litteraria e } \\
\text { recreativa }\end{array}$ & 1881 & $\begin{array}{l}\text { Club Dramatico Alumnos de } \\
\text { Minerva. "Redigida por uma } \\
\text { comissão de sócios" }\end{array}$ & Gratuito \\
\hline O Scenario & $\begin{array}{l}\text { Periodico do Club } \\
\text { Familiar Gymnasio da } \\
\text { Juventude }\end{array}$ & $1881-1883$ & $\begin{array}{l}\text { Club Familiar Gymnasio da } \\
\text { Juventude. Redatores e } \\
\text { proprietários: Othelo, Kean, } \\
\text { Hamlet e Duque de Richelieu }\end{array}$ & Gratuito \\
\hline O Scenario & $\begin{array}{lcc}\text { Jornal mensal do } \\
\text { Gremio Dramatico do } \\
\text { Meyer }\end{array}$ & 1901 & & $\begin{array}{l}\text { Era vendido, } \\
\text { mas sem preço }\end{array}$ \\
\hline O Theatro & & 1911 & $\begin{array}{lcr}\text { Diretor: } & \text { Nazareth } & \text { Menezes; } \\
\text { Secretário: } & \text { J. } & \text { Ozorio; } \\
\text { colaborador } & \text { efetivo: } & \text { João } \\
\text { Claudio } & & \\
\end{array}$ & $\begin{array}{l}\text { 200réis/ } \\
\text { Assinatura } \\
\text { anual 10\$000/ } \\
\text { semestral } 6 \$ 000\end{array}$ \\
\hline
\end{tabular}

Fonte: Informações reunidas a partir de leitura dos próprios periódicos localizados no Instituto Histórico e Geográfico Brasileiro e na Biblioteca Nacional.

Os almanaques eram publicados no fim do ano e apresentavam um panorama da cena teatral daquele período. Havia os periódicos publicados quinzenal, mensal ou semanalmente e ainda, os jornais pertencentes aos clubes dramáticos amadores que eram distribuídos nos dias de suas festas ou vendidos através de assinaturas. Voltarei a eles mais adiante. É importante lembrar que havia um número bem maior de jornais que tratavam dos assuntos teatrais. Esse levantamento parece ser um forte indicativo do lugar que o teatro ocupava na imprensa e que a própria imprensa ocupava na sociedade.

A circulação desses periódicos incluia desde a distribuição gratuita até a distribuição através de assinaturas, além da venda avulsa com preços que variavam entre 40 e 300 réis por exemplar, indicando que o público a quem se dirigiam era variado e, consequentemente, as notícias teatrais também eram dadas partindo de enfoques diferentes e formando plateias e opiniões também diversas. No entanto, as ideias dos intelectuais que escreviam para os grupos de elite, e que reproduziam um ideal de teatro inspirado na escola francesa, não estavam restritas aos periódicos de preço mais elevado. Muitas vezes, esses ideais eram reproduzidos 
por editores de jornais mais baratos, que podiam ser vendidos nos subúrbios ou mesmo distribuídos gratuitamente para determinados públicos. Não obstante, havia os periódicos que combatiam esse ideal de teatro e publicavam textos, folhetins, poesias, etc., que divulgavam outras visões acerca do fazer teatral. Os periódicos que mais contribuíram nessa investigação são, naturalmente, aqueles publicados e editados pelos próprios amadores e, especialmente, os que tiveram mais longa duração: A Lyra e O Scenario. No entanto, $O$ Espectador, apesar de não ser produzido por amadores, também foi bastante significativo para esta pesquisa.

\section{$O$ fazer teatral e o amadorismo nas páginas da imprensa teatral carioca}

O festival de teatro promovido pelo Centro Artístico, em 1898, tinha, segundo Orlando Teixeira - o jornalista responsável pelos comentários e críticas na Gazeta da Tarde - a proposta de "desenvolver, no público, o gosto pela Arte" ${ }^{»}$. Essa "associação de jornalistas e literatos que tinha como objetivo a promoção da arte brasileira"9 não estava preocupada com a educação do "povo", da "massa positivamente anônima, imbecil e à cata de sensações aqui, como em toda parte", mas de

\footnotetext{
uma certa camada, arredia e afastada do teatro por não sei quantas coisas pouco aceitáveis, entre as quais uma pseudo-moral avultava, camada alta, gente fina que só aparecia quando anunciados em algum teatro Emanuel, a companhia do teatro D. Maria II, a Lucinda, etc. ${ }^{10}$
}

O jornalista acreditava que, "pelo menos em grande parte", o objetivo do Centro Artístico teria sido atingido e que aquela "corrente de espectadores" seria maior em épocas futuras. Orlando Teixeira concordava com outros jornalistas que "o Teatro sairia do teatrinho dos amadores". Em 1906, Arthur Azevedo compartilharia a mesma opinião definindo os teatros de amadores como o "único viveiro de artistas"

Deixando clara sua compreensão de quem era o "povo" e quem era a "plateia fina" que frequentara o festival e demarcando as diferenças nos gostos teatrais desses dois públicos, Teixeira fortalece a opinião de outros intelectuais do seu tempo - como o próprio Arthur Azevedo, Coelho Netto, entre outros - que escreviam na pequena e grande imprensa e tentavam, sem muito êxito, imprimir a marca do "teatro sério" como teatro de qualidade. Este seria o drama e a alta comédia. O teatro ligeiro e as revistas eram considerados de mau gosto e agradaria apenas aos grupos mais populares. Mesmo sendo autor de inúmeras revistas, Azevedo abraçava esse discurso e viver publicamente essa contradição não parecia lhe incomodar. 
No entanto, a historiografia atual ${ }^{12}$ já demonstrou que o desvalorizado teatro ligeiro e as revistas não estavam restritas às camadas menos favorecidas, mas que seu público era heterogêneo e composto, inclusive, pelos grupos mais abastados e elitizados. Outro dado importante no comentário do jornalista da Gazeta da Tarde é o seu entendimento de que as peças de qualidade viriam dos teatros, companhias e artistas portugueses. É preciso acrescentar aqui a opinião daqueles outros literatos que concordavam que a Europa era onde se fazia o "verdadeiro teatro". Era inspirado nesse exemplo que os respectivos escritores desejavam que se desenvolvesse o idealizado "teatro nacional" que, segundo os mesmos, estaria em fase de decadência. Isto porque, apesar da vasta produção de peças de autores brasileiros, estas eram em sua maioria comédias ligeiras e musicadas, o que lhes excluía do dito teatro de qualidade.

Esse debate chegou, de certa forma, às linhas de Lima Barreto publicadas na revista $O$ Theatro, onde o autor entende que "o mal do nosso teatro" era o empresário, absolvendo os autores, atores, cenógrafos e maquinistas. Para esse escritor, "teatro é antes de tudo um comércio ou uma indústria e não há comércio sem iniciativa, sem ousadias de dinheiro, e sem faro especial"13. Acusando os empresários de não possuírem essas qualidades, Barreto esclarece o que era teatro em sua opinião: um negócio. E ainda que a preocupação dos empresários não era o público, mas sim a imprensa, priorizando seus repertórios de autores ligados a ela: eram articulistas, cronistas, repórteres e colaboradores. Bastante enfático nessa crítica, ele reclama do modelo de teatro imposto por Azevedo e reproduzido por outros autores ligados a imprensa dizendo que "temos que ficar nos moldes do Arthur, por causa da superstição da Imprensa, que os empresários tem, fazendo com que só raros ousem e tentem fazer qualquer coisa, raros esses sempre jungidos aos mesmo preceitos e preconceitos"14. Desmascarando autores conhecidos, ligados à imprensa, que pretendiam fazer o tal teatro de qualidade, Lima Barreto comenta que algumas peças de Coelho Netto, Paulo Barreto ou Medeiros e Albuquerque foram verdadeiros fracassos. No entanto, ele também rebate o comentário dos "entendidos" que dizem que o público não quer "coisas finas; quer pernas, maxixe e trolóló", justificando que "nem todas as peças mais ou menos obscenas vivem. Haja vista os vaudevilles nacionais que não conseguem ir adiante." ${ }^{15} \mathrm{O}$ escritor entendia, então, que teatro era um negócio e que para agradar o público e provocar enchentes desvinculadas na imprensa, era preciso representar novidades, colocar em cena novos autores com novas ideias e acabar com essa aliança entre empresários e imprensa. 
Vejamos uma outra compreensão de teatro publicada por uma "associação anônima", proprietária do periódico $O$ Espectador, definia como teatro na sua edição de 1883:

O teatro é a melhor tribuna, a melhor escola para combater e mostrar os vícios que corrompem uma sociedade. Por ele discute-se os mais difíceis problemas, e com vantagem, porque impressiona com arte o espírito do espectador, apresenta-nos sob a forma ridícula o vício; o perigo a que se expõem os que optam por semelhante mal, e discrimina as boas ações, os pequenos defeitos de educação de um povo e os próprios costumes que o orlam, dando uma perfeita fotografia dos elementos sociais, e são tratados na escola contemporânea pelo drama e pela comédia. ${ }^{16}$

No mesmo editorial, o periódico acrescenta que "pelo teatro pode se avaliar o grau de civilização de uma sociedade, porque [o teatro] é o espelho refletidor" dessa sociedade e que a abundância de peças francesas contribuiu para que ficássemos "viciados" na escola francesa. E termina comentando que a tendência em menosprezar o "verdadeiro teatro" deu "um golpe de morte na arte dramática". ${ }^{17}$ Ora é possível observar o sentido didático que o jornal atribuía ao teatro e seu papel na produção e divulgação de uma determinada moral que o jornalista julgava importante ser transmitida através do teatro. Esse periódico faz campanha em prol do "teatro brasileiro" questionando os interesses dos empresários teatrais que só montavam peças na certeza do "lucro fácil", criticando o excessivo recurso a peças estrangeiras, ele menosprezava o teatro ligeiro, valorizando as óperas e dramas. O sentido pedagógico do teatro parecia estar presente na compreensão de teatro para alguns jornalistas e literatos bem como sua intenção em influenciar os públicos que frequentavam as salas de espetáculos.

O Club Dramatico Gonçalves Leite, com sede em São Cristóvão, após vinte e seis anos de funcionamento e uma "espinhosa jornada", começou a produzir seu próprio jornal, intitulado $O$ Amador. Escrito pelos próprios associados e ponderando a "falta a ilustração e prática dos grandes escritores", mas sentindo "no sangue o vigor da força e na alma os raios do talento", parece concordar com a concepção d' O Espectador quanto ao papel pedagógico do teatro e sua função moralizante:

o Teatro é uma escola elevada, cuja missão é moralizar a sociedade ensinando-lhe como se desafronta graves ofensas, qual o fim sinistro de uma paixão ou vida desregrada, as flores que recebe os heróis do bem e os grilhões que o oprimem os heróis do mal. ${ }^{18}$

Os amadores do clube pareciam ter um conceito de "certo" e "errado" bastante definido e que deveria se expressar nas peças apresentadas no palco para que o público pudesse "aprender". O teatro tinha uma "missão" redentora! 
Uma outra forma de compreender o teatro, também com a intenção de instruir, mas através da diversão - não era uma "missão" -, era esclarecida pelo Arcadia Dramatica Esther de Carvalho no primeiro número de seu jornal, em 1888: o teatro representava a "luta sacrossanta da instrução pelo recreio" e aqueles que a essa luta se dedicavam "vivem e morrem em holocausto pela Moral e pela Liberdade". ${ }^{19}$ Mas, para além de educador em nome da moral e da liberdade, alguns amadores do mesmo clube divergiam dessa primeira compreensão e afirmavam que o teatro era a "cura" para as "úlceras sociais", podendo destruir superstições. Vejamos o destaque que o jornal deu logo na primeira página ao discurso do sócio e advogado Aurelio de Souza:

S. Ex. exaltou a arte dramática, como a escola viva dos nossos costumes apostemados de vícios; demonstrando que o teatro é o lutador; é o cautério das úlceras sociais; é o destruidor das superstições; é a lâmpada que jorra a luz da liberdade aos antros do despotismo, que tanto tem custado a fazer despejar o esconderijo. $(\ldots)^{20}$

Parece que o advogado associado ao Arcadia Dramatica fazia uma crítica aos problemas sociais e percebia o teatro como o "lutador" que destruiria as superstições e traria a liberdade no lugar do "despotismo". Ocupando, então, um lugar elevado no conceito do Sr. Aurelio de Souza, o teatro seria um espaço libertador e que poderia trazer mais justiça para a sociedade.

A favor da criação do Teatro Normal, ou seja, uma companhia nacional subvencionada pelo governo municipal e por isso mais estruturada ${ }^{21}$, estava Assis Vieira, redator de $O$ Paladino. O associado do Club Dramatico Alumnos de Minerva não via "estímulos no presente" e nem "esperanças no futuro" para artistas e amadores, sujeitos a "onda de estrangeirismo" que caíra sobre o teatro nacional. Endossando o discurso daqueles literatos que acreditavam na "crise do teatro nacional", o articulista discute, no entanto, a ideia do teatro normal, segundo ele, debatida entre "ilustrados representantes do jornalismo", "notáveis artistas que tem visitado este país" e "mesmo no próprio recinto do parlamento". Nas palavras de Vieira,

Para este desagradável estado da arte dramática, o único, o mais urgente e eficaz remédio é sem dúvida alguma a criação imediata de um teatro normal, onde aqueles que se sentem com decidida vocação para o palco, possam por em prova as suas aptidões e descortinar novos e mais propícios horizontes às suas aspirações artísticas. $^{22}$ 
Engajado nessa discussão que chegava ao governo, Assis Vieira defendia a distribuição de prêmios "àqueles que se distinguirem" e a criação de uma "pensão para os enfermos e idosos [que] não puderem mais trabalhar" no teatro. Se, de um lado, o associado do Club Dramatico Alumnos de Minerva apoiava o discurso de determinados intelectuais ligados aos grupos de elite, por outro, ele parecia ter ideias bastante modernizadoras e mais justas para os próprios artistas. Entendia teatro como uma "influência benéfica e moralizadora" exercendo influências "nos costumes e na educação do povo", sendo um "poderoso elemento de civilização e progresso". As "cenas passadas ao vivo nas tábuas do proscêncio, imprimem no espectador uma impressão mais violenta, e dão-lhe uma ideia mais exata, mais aproximada da execranda hediondez do vício e do crime, e do eterno triunfo da virtude e da justiça." Dessa forma, o teatro tinha a força para enviar mensagens e influenciar indivíduos.

O que se pode perceber através destes e outros testemunhos é que o teatro era compreendido pelos clubes dramáticos de formas diferentes e, às vezes, dentro de um mesmo clube seus associados divergiam. Assim, fosse uma "missão", um "recreio" ou até um "justiceiro", o teatro era transformador e esse era um motivo importante para pertencer a uma associação dramática de amadores.

Os objetivos de cada clube eram divulgados nos periódicos ou determinados nos seus estatutos, como no caso do Gremio Dramatico Cardonense, que esclarecia logo no seu primeiro parágrafo sua intenção de divertir-se dentro dos princípios morais: “as representações de dramas, comédias e outras diversões que obedeçam a tais princípios de moral". ${ }^{23}$ Já a Sociedade Particular Recreio Dramatico Riachuelense, localizada no Riachuelo, freguesia do Engenho Novo, tinha "por fim promover entre seus associados o recreio e instrução por meio de representações de dramas, tragédias, comédias, etc."24, ou seja, compreendiam teatro como diversão, mas não de maneira desassociada do pedagógico.

Os estatutos do Grupo Dramatico Theatro Social determinavam seus fins no artigo $3^{\circ}$ : "promover, logo que tenha capital bastante, a criação da Casa do Povo e propagar por meio de espetáculos, as modernas doutrinas sociais" ${ }^{\prime 25}$. O grupo amador anarquista deixa clara sua intenção em educar o público acerca das doutrinas libertárias. Essa discussão acerca do(s) objetivo(s) da "festa de propaganda" é amplamente discutida no trabalho de Hipólide, onde ele traz outros pesquisadores para essa discussão: Maria Thereza Vargas e Mariângela Alves de Lima afirmam que a cobrança da mensalidade pelos grupos reduziria "a possibilidade do prazer descomprometido" e demonstraria o trabalho doutrinário do grupo teatral, separando 
lazer e doutrinação. Foot Hardman chegou a mesma conclusão, afirmando haver uma "tensão permanente" entre esses dois propósitos dividindo os interesses das "massas" e das "direções". Hipólide compreende essa dissociação de forma "mais aparente do que real", afirmando que o teatro social combinava de maneira possível as intenções lúdica e doutrinária. ${ }^{26}$

Silvia Cristina Martins de Souza analisa atuação de José de Alencar em folhetins no Jornal do Commércio, quando tinha 25 anos de idade. Para ela, os folhetins eram "como ficções construídas pelo autor para passar a seus contemporâneos certas ideias e visões do mundo". ${ }^{27}$ Nesses folhetins o teatro era uma questão importantíssima: desde suas descrições físicas até seu "poder civilizatório". Podia-se educar a sociedade através da dramaturgia.

Encarando com seriedade o fazer teatral dos amadores, Satanás, o sócio amador e colaborador do periódico O Scenario, jornal editado pelo Club Familiar Gymnasio da Juventude, entendia que a "plateia é pública" e por isso ao pisar em cena, "perde-se o título de amador e vai-se figurar na galeria dos artistas". O folhetinista Othelo, do mesmo periódico, concordava com essa ideia porque, a partir do momento em que o público pagava para assistilos, isso os colocava na categoria de atores e não amadores. ${ }^{28}$

Sob o pseudônimo de Binóculo, o jornalista de A Lyra define o que entende por amador:

O amateur é um disco luminoso que se transforma num sol puro, mas que se deforma se lhe não evitarem os senões, que neste caso são os flocos do eclipse, que vão renascer a treva aonde devia brilhar um astro glorioso e potente. ${ }^{29}$

Os "senões" a que se refere são, na verdade, os problemas colocados pela crítica aos amadores. O rigor dessas críticas eram confirmadas pelo comentário de Arthur Azevedo em uma de suas crônicas: “em se tratando de récitas de amadores, a crítica perde naturalmente os seus direitos" $"$. Esse escritor sugeria que o teatro amador aproveitasse sua falta de interesse financeiro para ser um "educador de plateia", produzindo textos inéditos "de qualidade" de autores brasileiros, que fugissem ao gênero musical. Segundo ele,

A compensação do trabalho amador não é ser chamado à cena oito ou dez vezes, nem cinquenta, mas ter a consciência de haver contribuído para educar o gosto dos seus concidadãos.

Fazer com que estes aplaudam o mau teatro é abusar da inconsciência e da sua ingenuidade; é pervertê-los ainda mais; é arrancar-lhes do cérebro as últimas noções, que porventura lá se conservem, do que seja literatura dramática.

O Elite deve ser uma casa de ensinamento e, e preguemos o termo, de sacrifício, o que aliás não o impedirá de ser, antes de tudo, um lugar onde a gente se divirta. ${ }^{31}$ 
É importante notar que ele está falando do Elite Club, com sede na Tijuca, que tinha como sócios figuras pertencentes aqueles grupos mais abastados da sociedade e eram ensaiados inclusive pelo próprio comediógrafo, como em 1898 durante o festival do Centro Artístico, quando apresentaram a comédia de sua autoria, $O$ Badejo. Sendo um grupo de sócios da haute gomme, o Elite Club provavelmente não precisava cobrar ingressos. Porém, o comediógrafo parece homogeneizar todos os amadores e desconhecer que outros clubes, formados por trabalhadores de menor renda, precisavam da cobrança de ingressos para manter o próprio teatro e outras atividades oferecidas por esses grêmios. Era o caso da Associação Dramatica Particular Gil Vicente ou do Club Dramatico Alumnos de Minerva, entre outros. Dessa maneira, não é possível determinar a diferença entre atores profissionais e amadores na oposição cobrar ou não cobrar para assister peças, mas na maior autonomia dos amadores em relação às imposições de empresários e donos de companhias teatrais. Os repertórios dos clubes dramáticos amadores podiam ser escolhidos mais "livremente", não porque não precisavam cobrar ingressos, mas porque não precisavam se submeter as pressões dos empresários que só visavam lucros.

Na coluna Atores e ... Atores, da revista $O$ Theatro, assinada por J. Ozorio, o excesso de diminutivo para tratar da ascensão de artistas profissionais que começaram em palcos amadores revela o modo como o jornalista percebia o teatro amador:

Pequenos recitativos em família, mais tarde umas pontinhas no teatrinho particular do bairro e depois um ou outro papelinho de criado ou mordomo, numa ligeira comédia, representada num teatro público, em benefício, na noite de tiro. Finalmente, depois de umas tantas provações o indivíduo, pelo seu esforço e aptidão, ia subindo pouco a pouco, mas chegava a ser ator, senão de verdade, pelo menos não desonrava a classe.

A longa aprendizagem servia-lhe sempre para alguma coisa. ${ }^{32}$

Apesar de dedicarem uma coluna especial aos amadores, claramente os editores entendiam o teatro amador como "menor" e apenas uma "passagem" para se chegar ao teatro profissional. Danielle Crepaldi Carvalho analisa outra crônica de Arthur Azevedo apontando seu "zelo" de não criticar os amadores, que ocupavam lugar bastante diferente dos profissionais:

Arthur Azevedo pondera que, se já encontrava dificuldades para dizer a verdade aos atores de profissão, teria a pena "eternamente suspensa" se tivesse de analisar o desempenho de uma senhora da "haute gomme", além de ter de escutar um "Este sujeito trata-me como se eu fosse uma atriz!", caso fizesse uma observação desagradável sobre a mesma. ${ }^{33}$ 
A literata analisa as apresentações de duas peças de Coelho Netto, procurando observar como se dava a relação entre os artistas profissionais e amadores, a crítica e o público teatral. Ela comenta que não eram todos os amadores que almejavam tornarem-se profissionais devido ao olhar estereotipado de parte da sociedade carioca sobre os atores e atrizes. A permanência de um enorme número de artistas no teatro amador seria uma opção e não uma impossibilidade profissional. Essa opção tinha diferentes motivos: o mais comum citado entre os literatos, como o próprio Arthur Azevedo, era o medo de serem acusadas de falta de moral assim como as artistas profissionais, mas também podia ser porque atuar era o meio de expressar inúmeras ideias entre os seus pares, ou uma maneira de arrecadar dinheiro para os fins daquela sociedade, ou simples diversão; o fato é que o teatro amador era praticado por grupos que escolhiam essa forma de expressão para os seus mais diferentes propósitos.

O preconceito contra a profissão de ator podia se expressar nas próprias escolhas de repertórios por amadores e profissionais. A Morgadinha de Valflor, escrita pelo português Pinheiro Chagas, traz o personagem de um padre que demonstra a autoridade da Igreja Católica no julgamento das atrizes: "não tem salvação" e as "cômicas" ainda seriam "instrumentos de Satanás". A mãe de Leonor, protagonista da peça, concorda com o padre: "o teatro é um lugar de perdição" e conta que o pai de Leonor era camarista do rei D. José, mas quando era preciso acompanhar o rei ao teatro, "voltava as costas para a cena e rezava as suas contas" e agradece a "augusta soberana", D. Maria I, que "ordenou que no teatro da Rua dos Condes fizessem homens o papel de mulheres. Salvou a moral e a religião." 34

No entanto, a questão do preconceito não pode ser generalizada. Os grupos analisados por Carvalho são clubes dramáticos de amadores das elites cariocas para quem ser associado a preconceitos contra atores/atrizes podia ser um problema. Porém, para os trabalhadores de baixa renda ser chamado de ator/atriz poderia ser uma busca de reconhecimento social.

Além disso, a própria revista $O$ Theatro, de 1911, defende que "o verdadeiro ator brasileiro é um homem digno e de cultura". A coluna assinada por J. Ozorio defende que os "verdadeiros artistas" não sofrem preconceitos e podem ser "queridíssimos" na "alta sociedade" e nas "suas festas artísticas [que] são verdadeiras consagrações". O secretário da revista sugere, então, a organização de um "Centro, uma espécie de trust, de sorte que só poderá ser ator ou atriz, quem reunir umas tantas qualidades”. Essa pode ser uma explicação para a criação das sociedades dramáticas particulares: uma forma de enfrentar preconceitos formando atores de qualidade. Segundo o jornalista, para "causar satisfação a quem os recebesse", não precisariam ser "celebridades", mas deviam ser "educados, corretos e 
respeitadores" além de "modestos" e com "trajar limpíssimo". ${ }^{35}$ Então, um bom ator amador que tivesse esses quesitos não devia, de acordo com a visão de J. Ozorio, sofrer preconceito.

Mario Nunes, no primeiro volume de sua obra relembrando quarenta anos de teatro no Rio de Janeiro, colabora nesse debate entre amadorismo $\mathrm{X}$ profissionalismo, defendendo que era papel do governo criar escolas profissionalizantes para que o teatro pudesse atuar na “educação ao povo':

Não se explica porque razão o nosso governo cuida da música, da pintura e de outras artes e não cuida da arte de representar, principalmente quando é esta que mais aproveita à educação ao povo. O teatro será uma realidade neste país, no dia em que os poderes públicos se convencerem de que é preciso haver teatros como é preciso haver escolas. ${ }^{36}$

Vários testemunhos de contemporâneos registraram não apenas a competência dos artistas amadores, mas o número de profissionais que vieram desses palcos. Henrique Marinho, que em 1904 escreveu sobre a história do teatro brasileiro ressalta o amor desses artistas e escritores ao teatro, elogiando sua competência e diz que eles podiam formar companhias iguais ou melhores que as estrangeiras, de todos os gêneros, desde o trágico até o cômico; e cita alguns nomes de amadores que se tornaram profissionais como Ferreira de Souza, Eugenio Magalhães, Flavio Wandeck, Cinira Polonio, Mattos, Peixoto, Colás, Rosa Villiot, Ismenia dos Santos, Mario Arôso, Lucilia Peres e "a velha Clelia". ${ }^{37}$ Outros amadores que transferiram-se para os palcos comerciais são citados por Arthur Azevedo em várias de suas crônicas publicadas em A Notícia: Italia Fausta, Guilhermina Rocha, Leopoldo Fróis, João Luiz Paiva além dos portugueses que trabalharam no Rio de Janeiro: José Antonio do Vale, Maria Pinto, Luiza de Oliveira, Julia Moniz, Jesuína Saraiva, Carlos Leal e Alfredo Miranda. ${ }^{38}$

A revista $O$ Theatro, de 1911, em sua coluna dedicada ao teatro amador, legendou uma foto do ator Castello Branco dizendo: "inteligente e aplicado, começou sua carreira nos palcos particulares, revelando-se logo um amador corretíssimo. Fez parte da Companhia que trabalhou no Municipal". ${ }^{39}$ O jornalista Hermano Possolo, na coluna Actores, elogia a atriz Maria da Piedade, portuguesa que viveu no Rio de Janeiro, e começou sua carreira como amadora na Sociedade Esther de Carvalho, em 1893, representando o drama "O Poder de Ouro" e, com apenas 14 anos, já desempenhava o papel de Julia. ${ }^{40}$ Ou o ator José Bernardo Silveira, que começou trabalhando numa marcenaria e atuava na antiga Sociedade Dramática Filhos de Talma, seguindo para outros clubes, e que se tornou empresário de uma companhia 
teatral, porém teve prejuízo e foi trabalhar no Circo François, foi dirigido pelo ator Francisco Santos e após uma longa trajetória chegou ao Teatro Municipal. ${ }^{41}$

As pesquisas de Tiago de Melo Gomes e Fernando Mencarelli também abordaram a educação através do teatro acrescentando a questão da ambiguidade presente nos textos teatrais. Mesmo que o autor tivesse uma visão moralizante ou tendenciosa sobre qualquer assunto não estava garantida na recepção do público sua intenção inicial. Diferentes interpretações eram possíveis tanto por parte dos espectadores como pelos próprios diretores de cena e ensaiadores. Estes podiam enfatizar aspectos do texto cênico e minimizar outros através da interpretação, da movimentação em cena e mesmo através dos cenários, ressaltando ou desaparecendo com objetos e imagens descritas inicialmente pelo autor. Pode-se observar esse exemplo ao falar da peça $O$ Bilontra, de Artur Azevedo ou mesmo das peças onde a questão da modernização do Rio de Janeiro era o tema - e eram inúmeras. Ou seja, apesar da tentativa dos escritores para "educar" ou "civilizar" os espectadores com suas ideias, isso possibilitava diferentes leituras por parte da plateia. Se, para conquistar o público, as peças tinham que falar dos assuntos que incomodavam e que eram parte da vida deste público, então havia um diálogo aí entre textos, corpo cênico e plateias. Dessa forma, os efeitos estéticos e intelectuais dos significados produzidos através da leitura e interpretação de textos teatrais são múltiplos em função das diferentes formas de recepção e apropriação das suas mensagens.

\section{Fazer imprensa e teatro: por quê e para quê/quem?}

Em sua dissertação de mestrado acerca do periodismo suburbano, o historiador Leandro Climaco Mendonça destaca os espaços atribuídos pelos redatores desses jornais ao "progresso" vislumbrado nos bairros entre os quais estaria, exatamente, a "vida cultural e social' expressa na quantidade de associações musicais, carnavalescas e dramáticas atuantes, cuja programação era divulgada nessas páginas. Um dos periódicos analisados, por Mendonça é a Gazeta Suburbana, publicada em Todos os Santos, mas com agências e representantes em outros subúrbios:

\section{O que é verdade}

Que os subúrbios progridem isso é que não há contestar; e senão vejamos: São Cristóvão, tem sociedades de toda a espécie. Em São Francisco Xavier lá está o club Dramatico Itamarati, que, funcionando num belíssimo salão teatro, próprio, e sob uma administração criteriosa dá mensalmente a sua récita baile. Em Riachuelo, atesta-o o magnífico teatro construído em frente a estação, e outros pontos de reunião alegre familiar. No Engenho Novo há um distinto Club, onde as horas voam com os pares movidos por uma quadrilha de Mesquita ou uma polca de Callado. Há também uma boa associação musical, que graças à força de vontade e de bom gosto 
literário de seu ilustrado Presidente, secundado pelos demais digníssimos. Diretores e seus associados, constituiu-se, num momento, em associação, além de musical, dramática e onde também se dança, para a satisfação de todos os paladares. Em Todos os Santos há a sociedade Gremio Dramatico Familiar S. João Baptista, onde se passam noites bem agradáveis. (...) No Engenho de Dentro sustenta-se uma magnífica sociedade dramática; outra carnavalesca e ainda outra de música (...). ${ }^{42}$

Associando os clubes dramáticos e recreativos criados nos subúrbios ao "progresso" conquistado nesses bairros, a Gazeta Suburbana reforça a ideia da disseminação do teatro amador por toda a capital e os significados que essa presença podia imprimir no Rio de Janeiro. O fato da Gazeta Suburbana ter uma seção específica intitulada Palcos e salões já indica uma valorização dessa prática social e o destaque dado ao teatro amador pelos redatores desse periódico. Solidário a causa operária e na luta por melhorias nos subúrbios cariocas, esse jornal contou com a participação de José Roberto Vieira de Mello, militante do movimento operário, entre 1919-1920. Outros periódicos dedicados aos subúrbios também mantiveram seções que promoviam os eventos organizados pelas sociedades dramáticas e recreativas. Era o caso de $O$ Suburbio, com as seções Palcos e Diversões e Pelos Theatros ou a Revista Suburbana, na seção Palcos e Salões, entre outros. Como vimos na primeira parte desse artigo, inúmeros outros jornais, suburbanos ou não e com objetivos diferentes, reservavam um espaço para o teatro amador.

Para além dessa pequena imprensa local e de uma pequena imprensa teatral, havia ainda os periódicos mantidos pelos próprios grupos amadores que diferia da chamada grande imprensa não apenas na sua estrutura, mas também nas suas intenções, na sua forma de atuação e, evidentemente, no seu alcance junto ao público. Essa pequena imprensa não era um negócio lucrativo - muitos jornais eram distribuidos gratuitamente - o que já demonstrava objetivos bastante diversos na sua produção. Mas, o que pretendiam as sociedades dramáticas com a produção e circulação destes jornais? Vejamos algumas justificativas descritas pelos próprios responsáveis por esses periódicos...

O Scenario, jornal produzido e editado pelo Club Familiar Gymnasio da Juventude cinco anos após sua criação, tinha como endereço nos três primeiros números a Praça do General Ozorio n.33, mudando-se para a Rua da Alfândega n. 329. Seus redatores e proprietários assinavam Othelo, Kean e Hamlet. Na primeira página de sua primeira edição, ao contar a história do clube, o cronista anônimo revela que, em 1876, data da criação do clube, estavam localizados "na quadra em que de cada canto surgiam sociedades dramáticas, que pouco depois desapareciam sem deixar vestígios de sua passagem". Visto que a maior concentração de clubes estava no centro do Rio de Janeiro e, apesar dos pseudônimos, seus 
redatores eram associados, é possível concluir que o endereço da sede do Gymnasio da Juventude era na Rua da Alfândega, junto ao endereço do jornal publicado no seu quarto número. Em seu editorial está a justificativa para a entrada desses amadores na "arena jornalística":

\begin{abstract}
A imprensa é a mais poderosa arma do século.
Dizer aos socialistas que destruir não é persuadir, deter nas mãos desses deserdados da sociedade bacamarte dos salteadores, é sem dúvida uma grande missão, e a imprensa está reservado este humanitário cometimento.

$O$ Scenario órgão que ora surge a luz da publicidade, não é um núcleo de famigeradas ilustrações. Não se propõe a modificar os costumes, porque seria um arrojo inaudito da parte da mocidade que o dirige.

Entrando na arena jornalística, ele só tem por fim transpor para suas colunas; o que assistir representar sequer no palco público, quer no particular, o seu título bem demonstra seus fins. ${ }^{43}$
\end{abstract}

Sem pretensão de modificar costumes e entendendo que a imprensa é "uma arma poderosa", os redatores pretendiam apenas falar sobre o que as peças que assistissem nos palcos, fosse amador ou profissional. No entanto, qualificar a imprensa como "arma poderosa" pode indicar uma intenção maior do que o redator apresenta. As armas podem atingir física e mentalmente aqueles em quem miram e atiram. Claramente não havia a intenção de machucar fisicamente o leitor, mas, certamente, de influenciar suas ideias e gostos teatrais ou mesmo, através de críticas e crônicas sobre teatro, questionar formas de pensar e agir no cotidiano.

Menos agressivo, o periódico homônimo criado pelo Gremio Dramatico do Meyer, em 1901, dizia ter como único fim "lutar pela prosperidade e engrandecimento da associação da qual é ele o primeiro órgão", valorizando tanto a imprensa como o teatro, ainda que o redator anônimo estivesse bastante preocupado com seus "inimigos" e "rivais" na área jornalística. ${ }^{44}$

O "modesto órgão" $O$ Guarany pretendia "mostrar o grau de prosperidade desta sociedade dramática que, começando modestamente, com pretensão alguma, tem a satisfação e o orgulho de dizer que possui em seu seio a elite dos subúrbios". Entendendo-se capaz de "ombrear com as suas coirmãs", o editorial mostrava seu olhar sobre si mesmos, e acrescentava: "Negar-nos esse merecimento, seria falsear a verdade". Garantia ainda que a "prosperidade" do clube era amparada "pelo prestígio de distintos cidadãos e das Exmas. Famílias que honram nossa plateia". E deixava claro a importância de fundar no bairro do Engenho Novo "um ponto útil e agradável de diversões dramáticas, honrando assim o nome por demais glorioso do imortal artista brasileiro João Caetano dos Santos". ${ }^{45}$ Orgulhosos do 
jornal e do clube, os sócios pretendiam, além de se divertir, ser "úteis" às famílias que frequentavam sua plateia.

A Lyra, publicado pelo Arcadia Dramatica Esther de Carvalho, buscava na "literatura grega e a própria literatura romana" sua "norma" para "progredir" e pretendia "sobressair como deve, na sua altura de sociedade instrutiva", publicando um periódico "com mais brilhantismo" para "a história conceder-lhe um cantinho na posteridade. ${ }^{46}$ A Lyra pretendia, então, fazer do Arcadia Dramatica Esther de Carvalho uma sociedade "imortal".

Assis Vieira, do Club Dramatico Alumnos de Minerva, explica no editorial de $O$ Paladino o seu "modesto" intento:

proporcionar aos associados do clube uma agradável diversão para a inteligência, e procurar na proporção das limitadas forças dos seus empreendedores prestar uma justa e devida homenagem aos gloriosos vultos que tem honrado a arte dramática. ${ }^{47}$

"Modestamente", a intenção do periódico era, então, divertir os associados e homenagear os atores. É interessante que, de fato, os redatores deste jornal só mencionam em suas críticas os atores homens. Mesmo anunciando o programa das festas do clube com atrizes no corpo cênico, estas ficam "esquecidas" nas críticas e comentários sobre as peças. Essa observação é importante porque este foi o único periódico que deixou suas próprias amadoras no silêncio. Assis Vieira, que parece ser o sócio mais atuante no periódico fez uma poesia intitulada A Imprensa, deixando clara sua visão sobre a mesma:

\footnotetext{
Obreira do progresso! Na batalha incessante

Que dás ao crime, ao erro, à treva e ao despotismo,

E quebras do passado os laços do empirismo, Vibrando da justiça o gladio flamejante;

$\mathrm{Tu}$ - que galgas o espaço e levas bem distante Os arrojados vôos do pensamento humano, Que proteges o fraco e esmagas o tirano E dessa luta emerges altiva e triunfante;
}

Ah! Deixa que se acerque do teu poder ingente O novo Paladino que segue vacilante Da tua glória imensa a trilha refulgente.

Acolhe-o à tua sombra - potente e generosa,Envolve-o nos clarões da tua luz brilhante E encaminha-lhe os passos à meta gloriosa! ${ }^{48}$

O redator e poeta valoriza a imprensa e o seu "poder ingente", entendendo sua função no "progresso" da sociedade e na luta contra o "crime", o "despotismo" e a "tirania" e com isso "protegendo o fraco". Apesar de não tratar de política de forma direta, Assis Vieira, que 
assina todos os editoriais nas primeiras páginas dos quatro números conservados de $O$ Paladino, debate, por exemplo, a questão do associativismo recreativo e valoriza essas iniciativas como "partilha de interesses comuns" e reforça a ideia da diversidade social e da igualdade existente dentro dessas sociedades. Com diferentes objetivos, como a instrução, a caridade ou a diversão e a alegria, trabalham de forma coletiva para alcançá-los, proporcionando um convívio familiar não apenas entre os núcleos familiares, mas incluindo trabalhadores que vivem longe de suas famílias ${ }^{49}$. Sua compreensão acerca das sociedades recreativas aponta seu posicionamento político nos assuntos do cotidiano e sua percepção da necessidade de atuação civil para uma melhoria de qualidade de vida. Esse posicionamento se reflete também na forma "benéfica" como vê o teatro também como parte dessa atuação que influencia costumes e é, "depois do livro e da imprensa, o mais poderoso elemento de civilização e progresso" ${ }^{, 50}$. Sua forma de compreender a imprensa e seu papel político aparece nas suas opiniões de forma bastante clara e esclarecida.

Homenageando a atriz Aurelia Delorme, o periódico O Delormista: órgão consagrado ao theatro fluminense e ao grupo Delormista, era de propriedade de Guilherme Junior e publicado semanalmente. Sem pertencer ao Grupo Delormista, mas o consagrando junto ao teatro fluminense, o jornal teve apenas seu primeiro número conservado. Sem anúncios em nenhuma das suas quatro páginas e utilizando boa parte de seu espaço para comentários elogiosos à atuação e pessoa da atriz carioca, integrante da companhia Dias Braga. No editorial, esclarece a que veio:

Dedicando-se aos interesses do Theatro Fluminense, penetra no seu palco trazendo na mão direita a coroa de loiros que terá de ofertar àqueles dos artistas que se elevarem à sua conquista, e na esquerda mimosa cesta de vime donde só extrairá aplausos, ramalhetes e atos bons e justos.

Consagrado particularmente ao partido glorioso da exímia atriz Delorme, esse periódico saberá honrar-se, tornando-se digno êmulo desses moços esperançosos e entusiastas, que constituem o núcleo de seus dedicados partidários. ${ }^{51}$

A Madrugada, dedicado aos amadores do Euterpe Club, também esclarecem os motivos de sua publicação. No primeiro número, depois do editorial dedicado a Nepomuceno de Araújo - seu redator gerente, os redatores revelam os objetivos do jornal: "O nosso programa é único e exclusivamente literário, as nossas colunas jamais abrirão terreno para polêmicas, elas vem sem cor política e... nunca obedeceremos à crítica malévola porque a vemos nos lábios dos egoístas e dos invejosos". Na coluna intitulada “A nossa estrada!", eles dizem como se veem e o que entendem por imprensa: 


\begin{abstract}
Não é um facho de grandeza, aureolado por soberbos gênios, que desponta na madrugada de hoje, na radiante arena do jornalismo. Como vedes, é um pequenino periódico literário e recreativo, que se patenteia humilde e modesto, sem vislumbre de ostentação.

Não vimos preencher lacunas nem mostrarmo-nos perante o meio artístico, pois ainda falta-nos estudar muito e apenas temos desfolhado algumas folhas dessa tese monumental que se denomina - Imprensa! Magnânima inspiração do primoroso filho da pátria loira - Guttenberg, que tantos progressos tem trazido aos séculos e cujos alicerces, como pharões [sic] rutilantes, hão de sempre iluminar a ciência!

Contudo, confiados nas pequenas luzes que pálidas brilham nos nossos cérebros, com a grande força de vontade e energia, damos publicidade a nossa pequena Madrugada, se bem que a custa de milhares de sacrifícios. ${ }^{52}$
\end{abstract}

Depois de se mostrarem "humildes e modestos", os redatores contam sobre o convite recebido dos amadores do Euterpe Club para sua primeira matinê, o "entusiasmo" com que foram recebidos, quando receberam o pedido de que o jornal, recém criado, fosse dedicado ao Club e a expectativa de colaboração dos "amáveis consócios" por meio de assinaturas do periódico. A partir da reflexão sobre "alguns periódicos e sociedades criados por trabalhadores envolvidos com múltiplas formas de cultura letrada", a historiadora Laura Maciel afirma que "muitas vezes, os (...) redatores desses periódicos se desculpam perante o jornalistas profissionais (...) por sua má formação, e por se lançarem em tarefas para as quais não teriam a necessária qualificação". Mas, apesar dessas ressalvas, a autora mostra como alguns jornalistas amadores questionaram "o mundo fechado do jornalismo carioca" e outros "mostravam-se atentos aos debates linguísticos e literários travados por meio da imprensa contemporânea assumindo posição e preferências intelectuais", e ainda elenca algumas das motivações de grupos populares para produzir um jornal: a busca de educação ou instrução "para quebrar o monopólio dos espaços e mecanismos de poder" e "não apenas [pela] busca de ascensão social ou profissional"; a busca por "reconhecimento social" ou a utilização da escrita para formular e divulgar reivindicações populares ou, ainda, semear alguma crença ou princípio; podiam escrever também para deixar suas memórias ou informar como era a vida nos subúrbios; ou, como no caso do Vagalume, "contra um processo de apagamento e ocultação que, segundo ele, era promovido pela indústria fonográfica e pelo rádio." ${ }^{53}$

Se compreendemos "a imprensa como linguagem constitutiva do social, que detém uma historicidade e peculiaridades próprias" ${ }^{, 54}$ e que sua relação com a sociedade é reveladora de determinadas intenções, então a organização, produção ou colaboração em um jornal ou revista para o público do seu bairro ou os sócios da sua associação dramática, podem indicar quais as propostas daqueles periódicos e as estratégias criadas para dialogar com seus leitores. Dessa maneira, manter um periódico dedicado aos "interesses teatrais" ou escrever sobre 
teatro implica em selecionar as questões sobre as quais opinar - desde as peças e os grupos que vai se comentar até as causas e interesses a defender ou questionar - e, dependendo dessas escolhas, revela-se sua corrente de pensamento e que tipo de "produção de hegemonia" 55 sua atuação naquele meio social pretende constituir. É a partir dessa compreensão que a imprensa se firma, inclusive, como formadora de opinião e de públicos para o teatro, muitas vezes estabelecendo importante relação entre o jornal e os empresários teatrais ou os diretores de sociedades particulares.

Sendo assim, era bastante comum encontrar dramaturgos escrevendo para jornais ou mesmo administrando-os. Era o caso de Ernesto Mattoso, não coincidentemente, presidente do Gremio Dramatico do Meyer em 1912 e administrador da Gazeta Suburbana em $1910^{56}$. Mattoso escreveu duas peças teatrais: Um país essencialmente agrícola e Um verão em Petrópolis ${ }^{57}$. Conforme o próprio conta em suas reminiscências, escreveu também para o Cruzeiro e anos depois para a Gazeta da Tarde ${ }^{58}$. Entre outras histórias, o prodigioso escritor exemplifica a "confiança do povo pela imprensa" em um fato que aconteceu com ele em 1880: uma empresa teatral representava a peça $O$ Filho de Coralia, de Albert Delpit, com tradução "primorosa" de Henrique Chaves, porém não tinha público. O empresário Guilherme da Silveira pediu, então, ao jornalista que "escrevesse alguma coisa em favor da peça que tanto sucesso fazia em Paris e tão triste figura no Rio". Foi no lugar do folhetim do Cruzeiro de 12 de julho de 1880 que Mattoso escreveu sobre a peça. Dias depois o empresário teria voltado a redação para agradecer-lhe o "imenso serviço" afinal, desde então "o teatro era pequeno para conter os espectadores" ${ }^{\prime 59}$.

O testemunho de Mattoso mostra relações possíveis entre presidentes de sociedades dramáticas e jornais de circulação nos bairros inclusive, da relação entre empresários e jornalistas, e serve perfeitamente para mostrar como a imprensa agia não apenas como formadora de opinião, mas também de público, capaz de produzir e interferir no sucesso de peças, atores e companhaias dramáticas. A opinião de um "homem das letras" publicada nas páginas de um periódico podia, dependendo de sua importância e do número de exemplares em circulação, provocar "enchentes" nos teatros, bem como esvaziá-los. Não era à toa que vários periódicos da grande ou da pequena imprensa contavam com nomes como Arthur Azevedo, entre outros, para criticar ou divulgar peças, autores, empresários e, inclusive, clubes amadores. Compreendendo a imprensa como parte do real, força ativa que interfere no social, "muito mais ingrediente do processo do que registro dos acontecimentos", ela atua "na 
constituição de nossos modos de vida, perspectivas e consciência histórica"60, intervindo no cotidiano, inclusive, em escolhas como a peça que se vai assistir ou representar.

\section{Notas}

\footnotetext{
${ }^{1}$ Alguns desses títulos se encontram no IHGB, outros no Setor de Periódicos ou Obras Raras da Biblioteca Nacional. Muitos já estão disponíveis online na Hemerocea Digital da Biblioteca Nacional.

${ }^{2} O$ Theatro. Rio de Janeiro. Ano I, 4 de maio a 13 de julho de 1911.

${ }^{3}$ O Theatro. Rio de Janeiro. Ano I, n.2,4 de maio de 1911, p.9.

${ }^{4} O$ Theatro. Rio de Janeiro. Ano I, n.2,4 de maio de 1911, p.9.

${ }^{5}$ MENCARELLI, Fernando Antonio. O cartel dos tablados no Rio de Janeiro do século XIX: a empresa teatral
} internacional. In: WERNECK, Maria Helena e REIS, Angela de Castro (orgs.). Rotas de teatro entre Portugal e Brasil. Rio de Janeiro, 7Letras, 2012, p.111.

${ }^{6}$ A Epoca Theatral. Rio de Janeiro, Ano I, n.1, 22 de setembro de 1917, p.2.

${ }^{7}$ O Espectador. Órgão consagrado à Arte Dramática. Rio de Janeiro, Ano I, n 3, 5 de novembro de 1881. De propriedade de uma "associação anônima" o jornal inicia com periodicidade mensal e distribuição gratuita. A partir do terceiro número a periodicidade passa a ser quinzenal e a venda de exemplar avulso a 100 réis. Posteriormente o jornal passou a ser distribuído por várias agências e a contar com serviço de assinaturas por trimestre e semestre.

${ }^{8}$ Gazeta da Tarde. Rio de Janeiro, 14 de dezembro de 1898.

${ }^{9}$ COUTINHO, Júlia Alves. Um projeto de renovação teatral: O Festival do Centro Artístico e o teatro amador em 1898. Campinas, Monografia apresentada ao Instituto de Estudos da Linguagem, Unicamp, 2009. Entre outubro e novembro de 1898, o Centro Artístico realizou "seis espetáculos dramáticos que contou exclusivamente com atores e atrizes amadores. No programa estavam peças escritas (...) por três membros da associação, Coelho Neto, Artur Azevedo e Valentim Magalhães.” Op. cit., p. 6.

${ }^{10}$ Gazeta da Tarde. Rio de Janeiro, 13 de dezembro de 1898.

11 AZEVEDO, Arthur. O Theatro, A Notícia, Rio de Janeiro, 08/03/1906. In: NEVES, Larissa de Oliveira Neves e LEVIN, Orna Messer. (Orgs.). O Theatro, op.cit.

${ }^{12}$ MENCARELLI, Fernando Antonio. Cena Aberta - a absolvição de um bilontra e o teatro de revista de Arthur Azevedo. Campinas, Editora Unicamp, 1999; GOMES, Tiago de Melo. Um espelho no palco. Identidades sociais e massificação da cultura no teatro de revista dos anos 1920. Campinas, Ed. da Unicamp, 2004; entre outros.

${ }^{13}$ O Theatro. Rio de Janeiro, Ano I, n.2, 4 de maio de 1911, p.10.

${ }^{14}$ O Theatro. Rio de Janeiro, Ano I, n.2, 4 de maio de 1911, p.11.

${ }^{15}$ O Theatro. Rio de Janeiro, Ano I, n.2, 4 de maio de 1911, p.11.

${ }^{16}$ O Espectador. Orgão consagrado A Arte Dramatica. Rio de Janeiro, Ano III, $\mathrm{n}^{\circ}$ 17, 8 de julho de 1883.

${ }^{17}$ O Espectador. Rio de Janeiro, Ano III, $\mathrm{n}^{\circ} .17,8$ de julho de 1883.

${ }^{18}$ O Amador: periódico litterario do Club Dramatico Gonçalves Leite. Ano I. n.1. S. Cristóvão, 08 de setembro de 1888 , p.1.

${ }^{19}$ A Lyra: Orgam da Arcadia Dramatica Esther de Carvalho. Rio de Janeiro, Ano I, n.1, 8 de setembro de 1888.

${ }^{20}$ A Lyra: Orgam da Arcadia Dramatica Esther de Carvalho. Rio de Janeiro, Ano I, n.2, 10 de novembro de 1888, p.1.

${ }^{21}$ Apenas em 1926 é publicado o decreto n.3.745, criando o Teatro Normal. É apenas nessa data que aparece a primeira "companhia nacional de declamação para representação de dramas, comédias e peças de gênero clássico", subvencionada pelo governo municipal com isenção de "impostos de teatro e luz". Dois terços dessa companhia devia ser composto de artistas brasileiros natos e um terço de "artistas naturalizados ou nacionalizados, com mais de oito anos de efetividade nos teatros do Brasil".

${ }^{22}$ O Paladino: orgão do Club D. Alumnos de Minerva. Rio de Janeiro, Ano I, n.2, 25 de junho de 1881.

${ }^{23}$ Estatudos do Gremio Dramatico Cardonense, aprovados em maio de 1918. Arquivo Nacional. Caixa IJ6 691, DP.

${ }^{24}$ Estatutos da Sociedade particular Recreio Dramatico Riachuelense contidos no Decreto $\mathrm{n}^{\circ} 6.519$, de 13 de Março de 1877, Art. $1^{\circ}$. In: Coleção das Leis do Império do Brasil, Tomo XXV, Parte I e II, vol. 1, Rio de Janeiro, Typ. Nacional, 1877, p.179-184. 
${ }^{25}$ Bases Fundamentais do G. D. Theatro Social. Novo Rumo. 19 de setembro de 1906. In: HIPÓLIDE, Eduardo Gramani. O teatro anarquista como prática social do movimento libertário (São Paulo e Rio de Janeiro - de 1901 a 1922). Dissertação de mestrado em História pela PUC-SP, 2012, p.54.

${ }^{26}$ HIPÓLIDE, Eduardo Gramani. O teatro anarquista como prática social do movimento libertário (São Paulo e Rio de Janeiro - de 1901 a 1922). Dissertação de mestrado em História pela PUC-SP, 2012, p.55-56.

${ }^{27}$ SOUZA, Silvia Cristina Martins de. Ao Correr da Pena: uma leitura dos folhetins de José de Alencar. In: CHALHOUB, Sidney e PEREIRA, Leonardo Affonso de M. (org.). A História Contada - capítulos de história social da literatura no Brasil. Rio de Janeiro, Ed. Nova Fronteira, 1998, p.127.

${ }^{28}$ O Scenario: periodico do Club Familiar Gymnasio da Juventude. Ano II, n.6, 14 de janeiro de 1882, p.1.

${ }^{29}$ A Lyra: Orgam da Arcadia Dramatica Esther de Carvalho. Rio de Janeiro, Ano III, n.9, 15 de março de 1890, p.3.

${ }^{30}$ AZEVEDO, Arthur. O Theatro, A Notícia, Rio de Janeiro, 23/11/1905. In: NEVES, Larissa de Oliveira Neves e LEVIN, Orna Messer. (Orgs.). O Theatro, op.cit.

${ }^{31}$ AZEVEDO, Arthur. O Theatro, A Notícia, Rio de Janeiro, 28/12/1899. In: NEVES, Larissa de Oliveira Neves e LEVIN, Orna Messer. (Orgs.). O Theatro, op.cit.

${ }^{32}$ O Theatro. Rio de Janeiro. Ano I, n.2, 4 de maio de 1911, p. 20.

33 CARVALHO, Danielle Crepaldi. "Arte" em tempos de "chirinola": a proposta de renovação teatral de Coelho Netto (1897-1898). Dissertação de mestrado no programa de Teoria e História Literária da Unicamp, 2009, p.22.

${ }^{34}$ CHAGAS, Pinheiro. A Morgadinha de Valflor. Lisboa, Parceria Antonio Maria Pereira Livraria Editora, $12^{\mathrm{a}}$ edição, 1924, p. 89.

${ }^{35}$ O Theatro. Rio de Janeiro, Ano I, n.2, 4 de maio de 1911, p.22.

${ }^{36}$ NUNES, Mário. 40 anos de teatro. Vol.I, op.cit, p.58.

${ }^{37}$ MARINHO, Henrique. O Theatro Brasileiro (Alguns apontamentos para sua história). Rio de Janeiro, H.Garnier, 1904, p.93,94.

${ }^{38}$ NEVES, Larissa de Oliveira, LEVIN, Orna Messer (orgs). O Theatro - crônicas de Arthur Azevedo. Editora Unicamp, SP, 2009. As autoras fizeram um glossário dos artistas mencionados pelo cronista em um CD que acompanha o livro. Essas notas biográficas estão no arquivo do CD chamado "16 crônicas".

${ }^{39} O$ Theatro, Rio de Janeiro, n.2, 04 de maio de 1911, p.15.

${ }^{40}$ O Theatro, Rio de Janeiro, n.7, 08 de junho de 1911, p.24.

${ }^{41}$ O Theatro, Rio de Janeiro, n.8, 14 de junho de 1911, p.32.

${ }^{42}$ Gazeta Suburbana: folha recreativa, noticiosa e de interesses locais. Todos os Santos, 15 de dezembro de 1883, p.1-2. In: MENDONÇA, Leandro Climaco. Nas margens: Experiências de suburbanos com periodismo no Rio de Janeiro, 1880-1920. Dissertação de Mestrado em História. Niterói, 2011, p.91.

${ }^{43}$ O Scenario: periodico do Club Familiar Gymnasio da Juventude. Rio de Janeiro, Ano I, n.1, 9 de julho de 1881.

${ }^{44}$ O Scenario: jornal mensal do Gremio Dramatico do Meyer. Ano I, n.1, Capital Federal, 26 de outubro de 1901.

${ }^{45}$ O Guarany: órgão do Guarany-Club. Engenho Novo, Ano I, n.1, 1 de janeiro de 1903, p.1. Grifo meu.

${ }^{46}$ A Lyra: Orgam da Arcadia Dramatica Esther de Carvalho. Rio de Janeiro, Ano II, n.3, 12 de janeiro de 1889, p.1.

${ }^{47}$ O Paladino: orgão do Club D. Alumnos de Minerva. Rio de Janeiro, Ano I, n.1, 28 de maio de 1881, p.1.

${ }^{48}$ O Paladino: orgão do Club D. Alumnos de Minerva. Rio de Janeiro, Ano I, n.1, 28 de maio de 1881, p.4.

${ }^{49}$ O Paladino: orgão do Club D. Alumnos de Minerva. Rio de Janeiro, Ano I, n.3, 6 de agosto de 1881, p.1.

${ }^{50}$ O Paladino: orgão do Club D. Alumnos de Minerva. Rio de Janeiro, Ano I, n.2, 25 de junho de 1881, p.1.

${ }^{51}$ O Delormista: orgão consagrado ao theatro fluminense e ao grupo Delormista. Rio de Janeiro, Ano I, n.1, 31 de março de 1889, p.1.

${ }^{52}$ A Madrugada: periódico litterario e recreativo dedicado ao Euterpe Club. Rio de Janeiro, Ano I, n.1, 11 de janeiro de 1902, p.2.

${ }_{53}$ MACIEL, Laura Antunes. Cultura letrada, intelectuais e memórias populares. In: ENGEL, Magali Gouveia, CORRÊA, Maria Letícia, SANTOS, Ricardo Augusto dos. (orgs) Os intelectuais e a cidade - séculos XIX e XX. Rio de Janeiro, Contra Capa, 2012, pp. 68-77.

${ }^{54}$ CRUZ, Heloísa de Faria e PEIXOTO, Maria do Rosário da Cunha. Na oficina do historiador: conversas sobre história e imprensa. Projeto História, São Paulo, n.35, dez.2007, p.259.

${ }^{55}$ CRUZ, Heloísa de Faria e PEIXOTO, Maria do Rosário da Cunha. Na oficina do historiador, op. cit., p.259.

${ }^{56}$ MENDONÇA, Leandro Climaco. Nas margens: Experiências de suburbanos com periodismo no Rio de Janeiro, 1880-1920. Dissertação de mestrado em História. Niterói, 2011, p.94. 
${ }^{57}$ MATTOSO, Ernesto. Cousas do meu tempo (Reminiscências). Bordaux, Imprimeries Gounouilhou, 1916, p.282.

${ }_{58}^{5}$ MATTOSO, Ernesto. Cousas do meu tempo (Reminiscências). Op. cit., p. 325.

${ }^{59}$ MATTOSO, Ernesto. Cousas do meu tempo, op. cit., pp.311-319.

${ }^{60}$ CRUZ, Heloísa de Faria e PEIXOTO, Maria do Rosário da Cunha. Na oficina do historiador: conversas sobre história e imprensa. Op.cit., p.257.

\section{Referências Bibliográficas:}

CARVALHO, Danielle Crepaldi. "Arte" em tempos de "chirinola": a proposta de renovação teatral de Coelho Netto (1897-1898). Dissertação de mestrado no programa de Teoria e História Literária da Unicamp, 2009

COUTINHO, Júlia Alves. Um projeto de renovação teatral: O Festival do Centro Artístico e o teatro amador em 1898. Campinas, Monografia apresentada ao Instituto de Estudos da Linguagem, Unicamp, 2009.

CRUZ, Heloísa de Faria e PEIXOTO, Maria do Rosário da Cunha. Na oficina do historiador: conversas sobre história e imprensa. Projeto História, São Paulo, n.35, dez.2007.

ENGEL, Magali Gouveia, CORRÊA, Maria Letícia, SANTOS, Ricardo Augusto dos. (orgs)

Os intelectuais e a cidade - séculos XIX e XX. Rio de Janeiro, Contra Capa, 2012.

GOMES, Tiago de Melo. Um espelho no palco. Identidades sociais e massificação da cultura no teatro de revista dos anos 1920. Campinas, Ed. da Unicamp, 2004.

HIPÓLIDE, Eduardo Gramani. O teatro anarquista como prática social do movimento libertário (São Paulo e Rio de Janeiro - de 1901 a 1922). Dissertação de mestrado em História pela PUC-SP, 2012.

MACIEL, Laura Antunes. Cultura letrada, intelectuais e memórias populares. In: ENGEL, Magali Gouveia, CORRÊA, Maria Letícia, SANTOS, Ricardo Augusto dos. (orgs) Os intelectuais e a cidade - séculos XIX e XX. Rio de Janeiro, Contra Capa, 2012.

MENCARELLI, Fernando Antonio. Cena Aberta - a absolvição de um bilontra e o teatro de revista de Arthur Azevedo. Campinas, Editora Unicamp, 1999.

MENDONÇA, Leandro Climaco. Nas margens: Experiências de suburbanos com periodismo no Rio de Janeiro, 1880-1920. Dissertação de mestrado em História. Niterói, 2011.

NEVES, Larissa de Oliveira, LEVIN, Orna Messer (orgs). O Theatro - crônicas de Arthur Azevedo. Editora Unicamp, SP, 2009.

SOUZA, Silvia Cristina Martins de. Ao Correr da Pena: uma leitura dos folhetins de José de Alencar. In: CHALHOUB, Sidney e PEREIRA, Leonardo Affonso de M. (org.). A História Contada - capítulos de história social da literatura no Brasil. Rio de Janeiro, Ed. Nova Fronteira, 1998.

WERNECK, Maria Helena e REIS, Angela de Castro (orgs.). Rotas de teatro entre Portugal e Brasil. Rio de Janeiro, 7Letras, 2012.

\section{Fontes documentais:}

\section{Periódicos}

O Theatro, Rio de Janeiro. Ano I, maio e junho de 1911.

A Epoca Theatral. Rio de Janeiro, Ano I, n.1, 22 de setembro de 1917. 
O Espectador. Órgão consagrado à Arte Dramática. Rio de Janeiro, Ano I, Ano II, Ano III, 1881 a 1883.

Gazeta da Tarde. Rio de Janeiro. 13, 14 de dezembro de 1898.

O Amador: periódico litterario do Club Dramatico Gonçalves Leite. Ano I. n.1. S. Cristóvão, 08 de setembro de 1888.

O Scenario: periodico do Club Familiar Gymnasio da Juventude. Ano I, Ano II, 1881 e 1882.

O Scenario: jornal mensal do Gremio Dramatico do Meyer. Ano I, n.1, Capital Federal, 26 de outubro de 1901.

O Guarany: órgão do Guarany-Club. Engenho Novo, Ano I, n.1, 1 de janeiro de 1903.

A Lyra: Orgam da Arcadia Dramatica Esther de Carvalho. Rio de Janeiro, Ano I, Ano II, Ano III, 1888 a 1890.

A Madrugada: periódico litterario e recreativo dedicado ao Euterpe Club. Rio de Janeiro, Ano I, n.1, 11 de janeiro de 1902.

O Paladino: orgão do Club D. Alumnos de Minerva. Rio de Janeiro, Ano I, n.1,2,3, maio a agosto de 1881.

O Delormista: orgão consagrado ao theatro fluminense e ao grupo Delormista. Rio de Janeiro, Ano I, n.1, 31 de março de 1889.

\section{Documentos da polícia:}

Estatudos do Gremio Dramatico Cardonense, aprovados em maio de 1918. Arquivo Nacional. Caixa IJ6 691, DP.

Estatutos da Sociedade particular Recreio Dramatico Riachuelense contidos no Decreto $\mathrm{n}^{\mathbf{o}}$ 6.519, de 13 de Março de 1877, Art. 1º. In: Coleção das Leis do Império do Brasil, Tomo XXV, Parte I e II, vol. 1, Rio de Janeiro, Typ. Nacional, 1877.

\section{Peça teatral:}

CHAGAS, Pinheiro. A Morgadinha de Valflor. Lisboa, Parceria Antonio Maria Pereira Livraria Editora, $12^{a}$ edição, 1924.

\section{Memórias:}

MARINHO, Henrique. O Theatro Brasileiro (Alguns apontamentos para sua história). Rio de Janeiro, H.Garnier, 1904.

MATTOSO, Ernesto. Cousas do meu tempo (Reminiscências). Bordaux, Imprimeries Gounouilhou, 1916.

NUNES, Mário. 40 anos de teatro. Rio de Janeiro, SNT, 1956, vol. I (1913-1920). 